\title{
A Study on Customer Analytics Initiative (WCAI) and its Impact on the Brand of Wharton Business School
}

\author{
Sachin Kumar ${ }^{1 \& 2}$, Krishna Prasad K. ${ }^{3}$ \& P. S. Aithal ${ }^{4}$ \\ ${ }^{1}$ Dept. of Computer Science, Noida Institute of Engg. \& Tech., Greater Noida, U.P., India \\ E-mail: sachinks.78@gmail.com \\ ${ }^{2}$ Post Doctoral Research Fellow, College of Computer Science and Information Science, \\ Srinivas University, Mangalore, India \\ ${ }^{3}$ College of Computer \& Information Science, Srinivas University, Mangalore, India. \\ ${ }^{4}$ College of Business Management \& Commerce, Srinivas University, Mangalore, India
}

Area of the Paper: Computer Science.

Type of the Paper: Research Case study.

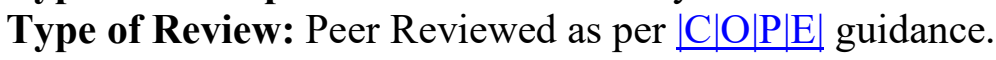

Indexed In: OpenAIRE.

DOI: http://doi.org/10.5281/zenodo.4008850.

Google Scholar Citation: IJCSBE.

\section{How to Cite this Paper:}

Kumar., Sachin, Krishna Prasad, K., \& Aithal, P. S. (2020). A Study on Customer Analytics Initiative (WCAI) and its Impact on the Brand of Wharton Business School. International Journal of Case Studies in Business, IT, and Education (IJCSBE), 4(2), 98-109.

DOI: http://doi.org/10.5281/zenodo.4008850.

International Journal of Case Studies in Business, IT and Education (IJCSBE)

A Refereed International Journal of Srinivas University, India.

(C) With Authors.

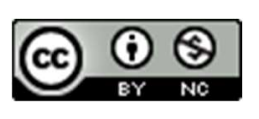

This work is licensed under a Creative Commons Attribution Non-Commercial 4.0 International License subject to proper citation to the publication source of the work.

Disclaimer: The scholarly papers as reviewed and published by the Srinivas Publications (S.P.), India are the views and opinions of their respective authors and are not the views or opinions of the S.P. The S.P. disclaims of any harm or loss caused due to the published content to any party. 


\title{
A Study on Customer Analytics Initiative (WCAI) and its Impact on the Brand of Wharton Business School
}

\author{
Sachin Kumar ${ }^{1 \& 2}$, Krishna Prasad K. ${ }^{3} \&$ P. S. Aithal ${ }^{4}$ \\ ${ }^{1}$ Dept. of Computer Science, Noida Institute of Engg. \& Tech., Greater Noida, U.P., India \\ E-mail: sachinks.78@gmail.com \\ ${ }^{2}$ Post Doctoral Research Fellow, College of Computer Science and Information Science, \\ Srinivas University, Mangalore, India \\ ${ }^{3}$ College of Computer \& Information Science, Srinivas University, Mangalore, India. \\ ${ }^{4}$ College of Business Management \& Commerce, Srinivas University, Mangalore, India
}

\begin{abstract}
The Wharton Customer Analytics Initiative (WCAI) is the leading academic research center that focuses on the development and application of customer analytics methods. WCAI is the leading academic research center in the world that focuses on the development and application of customer analytics methods. The innovative Research Opportunity Platform and the "crowd sourcing" approach to R\&D, WCAI helps academic researchers from around the world understand how to effectively monetize consumer data collected by developing and applying new predictive models to businesses. The authors couple their work with companies and researchers around the world with a variety of co-curricular student programs that facilitate talent development and recruitment. Started with a generous donation from Wharton alumnus Art Bilger and his wife, Dahlia, and with an executive relationship with Omnicom Group, Inc. WCAI has a significant impact on data-driven corporate decision-making processes and on the dissemination of vital information to managers, students, and policy-makers. Customer Analytics refers to the collection, handling, evaluation, and systematic exploitation of a company's granular data regarding the behaviours of its customers. In this paper, we analyzed the features and impact of the Wharton Customer Analytics Initiative (WCAI) on different stakeholders.
\end{abstract}

Keywords: Customer Analytics, Wharton Customer Analytics Initiative (WCAI), Impact of customer analytics on WBS brand.

\section{INTRODUCTION :}

Business case studies on various issues of an organization lead to a new interpretation of existing knowledge of business management [1-2]. New methods of quantitative data analysis from collected big data from different stakeholders or different business parts or business issues lead to descriptive, predictive, and prescriptive data analytics. There are many data analytics used for improving business decisions and business value for various stakeholders. The Wharton customer analytics initiative (WCAI) is the world's leading research center that focuses on customer analytics methods creation and implementation [3]. WCAI is the convergence of academia and business enabling students and academic researchers to help businesses understand that thing. The positive relationship between multichannel buying and consumer productivity is one of the most fascinating and managerially important results in multichannel customer management literature. The problem is whether the relationship is actionable, causal. To investigate this issue, the author's design and implement a randomized field experiment [4]. The field experiment tests four marketing campaigns which differ in communications message and financial reward provision. The relationship between multichannel and productivity is actionable. A properly planned marketing strategy improves the number of multi-channel customers and the average profitability of the customers. Most competitive industries find it difficult to define their competition set, and given the generally recognized importance of competition set to strategy development and day-to-day operations, few data-driven strategies have been established to address 


\section{International Journal of Case Studies in Business, IT, and Education SRINIVAS (IJCSBE), ISSN: 2581-6942, Vol. 4, No. 2, August 2020. \\ PUBLICATION}

this challenge [5-6]. Non-profit organizations use direct-mail marketing to grow and turn single-time donors into regular supporters. Cultivated donors produce a lot more revenue than new donors, but they also expire over time, making it necessary to draw on new cultivations steadily. This shows through simulation that a clear design approach based on such observations can increase performance levels from $5.4 \%$ to $8.1 \%$ [7]. Online shopping eliminates the expense of obtaining information about a commodity's price and availability, and of flexible timing of the order. Therefore, buyers should strategically schedule their purchases, balancing the monitoring costs and the risk of inventory loss against prospectively lower prices. at the same time, businesses are monitoring and taking advantage of their customers' monitoring behaviour. It estimates that the retailer's profit under randomized markdowns is $81 \%$ higher than the subgame-perfect state-contingent point because the retailer does not need to limit its inventory to markdowns in a reliable manner that allows its jointly optimal inventory to increase by $133 \%$. Welfare profits from these wider inventories divided between retail profit and consumer surplus nearly evenly [7]. Established in 1881 as the first undergraduate business school, the Wharton School of the University of Pennsylvania is globally known for intellectual leadership and continuing innovation in every major discipline of business education. Wharton creates economic and social awareness worldwide through a large global network and one of the most highly known faculties of business schools [8].

\section{OBJECTIVES OF THE STUDY :}

The objective of this case study on initiative of Customer analytics include:

(1) To learn basic idea about Emerging field of Analytics.

(2) To discuss the potential education analytics in $21^{\text {st }}$ century.

(3) To study an overview of customer analytics.

(4) To find the objectives and focus of Wharton Customer Analytic Initiative (WCAI) Centre.

(5) To discuss the impact of WCAI on brand of Wharton business school.

(6) To analyse and compare other Customer Analytics Initiative with WCAI Model.

\section{EMERGING FIELD OF ANALYTICS :}

The field of data analytics is mainly concerned to extracting useful information from pool of interrelated data and has following variations :

(1) Transactional data- Transactional data via retail, where each transaction deepens awareness of the movements of a company's customers.

(2) Data about service/product use- Manufacturers may analyze the product usage data to build and evolve a better customer experience.

(3) Web behavior data- Ecommerce retailers are using predictive analytics to monitor consumer behavior, classify consumer preferences, and make product recommendations.

(4) Data from customer-created texts- Customers take the opportunity to express their personal experiences of a product or service in the form of an online review or social media message. Social media analytics is planned to draw its rivals to clients.

(5) Forecasting and predictions analytics- Predictive analytics is no wonder as Artificial Neural Networks carry analytics to the next level as they catch a multi-factor-based pattern and have the best prediction. The effect is not necessarily eliminating ambiguity but mitigating it.

(6) Agile analytics for dynamic markets- Power BI offers versatility and is similar to Excel. It is also reliable, minimizes human error and can be used enterprise-wide. Power BI can use Azure capabilities to work with big data.

(7) Integrating external data- Cloud and API technologies allow data to be quickly and cost-effectively obtained from supply chain partners and data providers [9-10].

\section{EDUCATION ANALYTICS :}

Learning analytics is tracking, collecting, analyzing, and reporting learner data and their experiences to understand and improve learning and the environments in which it occurs. 


\section{Data Analytics}

The team is using a co-build methodology to help you take the data you have and use it in comprehensive, creative ways to understand your students, teachers, and leaders better. The various skill areas provide us with a range of reflective and practical methods of data analysis.

\section{Data Reporting and Visualization}

The team implements a co-building process with stakeholders using cutting-edge analysis and visualization methods to bring analytics directly into the hands of consumers in practical, actionable ways. $r$ team also provides comprehensive dashboards for data that allow users to monitor, explore, and dive into their data.

\section{Technical Assistance}

The team provides technical assistance (TA) during the life cycle of programs and policies to partner organizations, including design, execution, quality improvement, sustainability, and scale-up.

\section{Privacy of Student Records Collected and Maintained by Education Analytics}

Education Analytics adheres to the privacy provisions of the 1974 (FERPA) Act, as amended by the California Constitution, and all other relevant federal and state laws and regulations that safeguard education information, anonymity, and confidentiality, for all student data collected by Education Analytics [11-12].

\section{AN OVERVIEW OF CONSUMER ANALYTICS :}

Consumer analytics is a method of gathering and analyzing consumer data to understand customer behavior and expectations for making strategic and tactical business decisions, as well as generating customized recommendations automatically. It's sluggish and many companies struggle to grasp as much as they want their customers.

- Market management, marketing, and sales decisions are not ideal, resulting in failed products, slow development of new customers, and the need to offer more offers to keep sales stable.

- The forecast is not sufficiently precise, leading sometimes to stock-outs or excessive production/inventory.

- The method of gathering and analyzing consumer data is designed to understand consumer behavior and expectations for strategic and tactical business decisions, as well as to automatically formulate personalized recommendations.

- A ready-to-use customer analytics platform to incorporate a customer analytics approach with the in-house team's efforts and include a consultant and implementation partner to outsource customer data analytics [13].

\section{WHARTON CUSTOMER ANALYTICS INITIATIVE (WCAI) :}

The Wharton Customer Analytics Initiative (WCAI) is the world's leading academic research center focusing on the creation and implementation of customer analytics methods. Through the creative R\&D Incentive Research platform and crowd sourcing approach, and through creating and implementing innovative statistical models, WCAI allows independent researchers from around the world to help companies learn how to effectively monetize the individual-level data they gather about consumers. This pair working with companies and researchers worldwide with a variety of student cocurricular programs that facilitate talent creation and recruitment. If a firm has data to evaluate, wants a path map to launch, or somewhere between, WCAI encourages them to apply to the Accelerator Challenge. Although businesses from all business sectors are welcome to apply, start-ups and nonprofits are particularly encouraged, given they have a designated point person who can commit for four weeks 10 hours a week. WCAI must recognize the participation of up to three winners in the engagements. Winning companies should go away with realistic, transformative results in the form of a strategic plan, digital code, data files, or something more custom-made based on the unique needs of the client. Students will gain exposure to companies facing real-world data and analytics issues. The Wharton Customer Analytics Initiative (WCAI) is the world's leading academic research center focusing on the development and application of customer analytics methods in the real world. The project has a broad impact on data-driven business decision making practice and the diffusion of relevant insights to students and industry professionals through the innovative learning opportunities program, co-curricular training programs, and professional events. Wharton Customer Analytics Initiative Conference brings 


\section{International Journal of Case Studies in Business, IT, and Education SRINIVAS (IJCSBE), ISSN: 2581-6942, Vol. 4, No. 2, August 2020.

data back to life, moving beyond the numbers and showing everyone how to connect that to their strategic initiatives. To create and implement effective market and monetization strategies, they must build a data-analytic mentality, understanding how to turn numbers into actionable insights. One can also learn how to use compelling storytelling to communicate data-driven recommendations [14-15].

\section{IMPACT OF WCAI ON THE BRAND OF WBS :}

The Wharton customer analytics initiative is the world's leading academic research center focused on the development and implementation of customer analytics methods. With the innovative "crowdsourcing" platform for research opportunities and R\&D strategy, WCAI allows independent researchers from around the world to help businesses understand how customer-specific data collected can be efficiently monetized by creating and applying new predictive models. To develop their internship and future career skills in data processing, we offer a variety of educational, extracurricular professional workshops and self-guided training courses for MBAs \& undergraduates [21]. What allows independent researchers around the world to help businesses understand how to efficiently monetize customer-specific data gathered through the creation and implementation of innovative predictive models. The proprietary network of earth networks for weather tracking contains more than 20,000 unique and professionally controlled weather stations, which are updated with live data every two seconds. And with more than 1,800 sensors in over 100 countries, total lightning networks on earth are the biggest and most technologically advanced lightning networks in the world. Through this partnership, we will exploit the weather knowledge of earth networks for a wide range of use cases including:

- Work to advance analytics through industries affected by temperatures, such as telematics, aviation, insurance, retail, and many others.

- Faculty-advised programs for undergraduate and graduate students at the University of Pennsylvania and scholars associated with universities around the world.

- Development of creative analytical models and technological solutions with potential for commercial sector deployment.

- Integrating curricula, lesson plans, or assignments into structured courses.

The authors are excited to join the Wharton school customer analytics project to bring advanced weather intelligence and lightning data into the hands of top researchers and students who are committed to increasing the use of weather data in analytical applications. Real-time and locationbased perspectives are becoming increasingly important to organizations addressing the growing role of weather in their operations, and this partnership aims to tackle this challenge. The partnership with earth networks is a gamechanger in giving access to real-time weather data and analytics for their faculty and student researchers. The combination of weather intelligence data from earth networks and their data analytics tools will accelerate the creation and deployment of new forecasting models for a wide variety of business sectors and provide unparalleled access to weather data for the University of Pennsylvania community. Customer base analysis uses information on the history of consumer purchasing habits to answer forward-looking problems such as which people are more likely to be Successful customers in the future, and what the "lifetime value of customers" could be for a category of customers identified in the company's database. Senior management has paid a growing number of practitioners to get clear answers to these kinds of questions. No special programming skills are needed by its users; all will be done using good old Microsoft Excel Software. Here, businesses gaining a major competitive edge in a market environment where data analysis and predictive analytics have become important keys to understanding consumers and developing successful corporate strategies. The University of Pennsylvania's Wharton School is known for strategic leadership primarily on a global scale. It is also renowned for consistent creativity across major business education disciplines. The Wharton customer analytics initiative, also known as WCAI, is recognized as a prestigious research canter for academic study. Marketing professionals and researchers are facing some of the most exciting Challenges in data analytics today with ample and growing consumer data. WCAI will convene leading minds from various disciplines to share their data analytics and marketing experiences, drawing on their experience in finance, information technology, statistics, computer science, and other related fields. WCAI would have had a broad influence on data-driven business decision-making practice and disseminating valuable information to executives, students, and policymakers. It is an 


\section{International Journal of Case Studies in Business, IT, and Education SRINIVAS (IJCSBE), ISSN: 2581-6942, Vol. 4, No. 2, August 2020.

interdisciplinary initiative that carries with it a dedicated, data-driven point of view which no other business school can match. Wharton's Customer Analytics Initiative (WCAI) plays matchmaker among non-profit and research teams around the world. The initiative has established a specific framework for linking researchers with different corporate partners' opportunities. The aim is to inform business, government, and non-profits about how academics can respond to their concerns and build strategies for analyzing consumer data at the person level [16-17].

\section{OTHER CUSTOMER ANALYTICS INITIATIVE BASED ON WCAI MODEL :}

Learning analytics is the assessment, collection, analysis, and reporting of learner data and its implications to recognize and enhance learning and the environments in which it occurs. The growth of online learning since the 1990s has led to the development of Learning Analytics, especially in higher education, as student data can be collected and made available to analysis. Via conversation, learners can track their clicks, navigation habits, time on task, social networks, information transfer, and idea development using an LMS, social media, or similar online tools. Rapid establishment of massive open online courses (MOOCs) offers additional data for researchers to assess teaching and learning in online environments. This is the use of intelligent data, learner-generated data, and research models to discover information and social interactions to predict and inform people on learning. Universities strive to open the black box of education using learning analytics tools by tracking, aggregating, and analyzing student profiles along with the students' digital and analog behaviors reported in information systems. Nevertheless, the increase in and use of sensitive, personal student data poses unique privacy concerns. He argues that privacy as control of personal information facilitates autonomy and that students should be told about these flows of information and for what reason their organization is using this. Informed consent is one method for achieving certain targets, but big data activities question this strategy's effectiveness. To reshape the educational landscape, educational institutions and school systems are now facing several critical considerations. Whether it is preparing for reopening, transitioning to online learning models, or ensuring that the needs of students are met, they need trustworthy data to support their choices throughout their journey. At any stage with data-driven decision-making at COVID19, Tableau will enable schools and institutions to utilize trusted tools during this unprecedented period. Use this website to see how Tableau is used by universities and schools to assess student progress, build interactive factbooks, and coordinate operations across campuses and districts. As COVID-19 has advanced around the world, many special and unparalleled difficulties have been faced with school districts. Although each school district is facing these challenges, the community has decided to tackle them with data head-on to ensure that students continue to be successful. Analytics as one of the new technology-based learning fields offers many advantages for students, teachers, and administrators in improving the efficiency and quality of alternative educational services, and learning experience by tracking and storing student log data on online platforms for an extended period. This mixed-method analysis investigates the log data obtained from the explicitly launched open courseware (OCW) for a required English-speaking academic skills course offered at the Middle East Technical University in Turkey to enhance the quality and efficiency of the materials available for the course. By determining the factors behind the students' actions through interviews with 50 students on this online courseware, this study also aims at giving teachers practical input and motivating them to take action on future decisions. The data reviewed cantered on learner behavior with an emphasis on average viewing time, likes and dislikes, and comments. This work will serve as a starting point for guiding and presenting the future of the aforementioned course to the teachers and administrators, which is also provided in a rotational hybrid learning setting where the utility of online resources is gaining even greater importance [17]. Educational data analytics are used to research the data available in the field of education and to extract the secret information from it. Analytics is a method in which important trends from vast quantities of data are found, analyzed, and interpreted. Information analytics-based data mining techniques such as classification, comparison, correlation, categorization, prediction, estimation, clustering, analysis of patterns, and visualization. Predictive analytics can help boost the quality of education by supplying decision-makers with the right knowledge to make informed decisions. The need for data analytics to be applied in the educational sector indicates several approaches for utilizing these needs. The understanding of various components and their functions is needed during the implementation of any program. There are various 


\section{International Journal of Case Studies in Business, IT, and Education SRINIVAS (IJCSBE), ISSN: 2581-6942, Vol. 4, No. 2, August 2020.

components in Educational Management System such as technology, content, programs, e-learner, etc. Key issues related to these components and their roles within the framework such as service to be delivered, requirements for content design. Educational data analytics can discover, evaluate, and forecast practical information from educational data that will assist in a robust planning, execution, and future prediction education management framework [17]. Analytics typically refers to the process of gathering data, performing those analyses, producing related observations, and making (what advocates hope would be) smarter decisions with that new knowledge. Public schools and ed-tech firms have been experimenting with both for years, usually with two aims in mind: to further personalize teaching, by tailoring the learning experience to the individual talents, abilities, and interests of each student; and to encourage more data-driven operational decisions [18]. Some of the educational analytics that becomes popular now are:

(i) Microsoft Analytics:

Microsoft Workplace Analytics uses data from Microsoft 365's daily work to deliver a comprehensive view of organizational trends, enabling companies to operate with efficiency, improving employee interactions, and sharpening company attention.

(ii) Agile Analytics:

Agile analytics is a method for exploring data that focuses on discovering meaning in a dataset, using a freeform adaptive approach rather than testing hypotheses. Ultimately, when applied as part of a collaborative process and when there are certain underlying assumptions regarding the process, agile analytics perform best. This data analysis approach provides users with the versatility and adaptability to get through data sets that provide little real benefit and can eliminate prejudices by concentrating on the process of discovery rather than trying to validate hypotheses. Agile analytics will help businesses minimize their overheads and continually find new ways to look at the data they obtain in a more valueoriented process of exploration.

(iii) SAS Analytics:

SAS (formerly "Computational Analysis System") is a statistical software system for data processing, advanced analytics, multivariate analysis, business intelligence, criminal enforcement, and predictive analytics developed by SAS Institute.

(iv) Hamill Educational Analytics:

With a Ph.D. in Higher Education and a Virginia Tech Academic Research Certification, Dr. Hamill has spent her career working in the higher education sector. She has worked in Admissions, Student Education and Engagement, as well as with numerous initiatives for exposure. Hamill Education Analytics brings to its clients the customized support of a small business, as well as the expertise and knowledge of both an educator and a higher education professional. Dr. Hamill also calls on her strategic and mathematical experience to work on a variety of projects. Recent work covers a comparative analysis of a school reaccreditation scheme, planning for a regional access program, and a 6year review of a national and international grant renewal study program

(v) GitHub Educational Analytics:

These analytics was created using Jupyter Notebook, iPython, Python, Anaconda, Spyder IDE, and PyCharm JetBrains. This repository is based on some practical machine learning exercises and examples, using some libraries such as NumPy, Matplotlib, SciPy, Pandas, and TensorFlow to work on some datasets, among many others.

(vi) Assembly Analytics:

Community Brands Assembly Analytics has been developed with input from multi-academy trusts around the UK including Ark and Astrea, making it one of the leading-platforms for data analysis in the education sector today. The easy but creative dashboards integrate the key MIS data with structured assessment and financial data to provide learner with accurate metrics for confidence in his/her academies and multi academies. Find out more below and get in touch to find out how Assembly Analytics can improve the learner data analysis and helpshis/her gain useful insights into their trust [19-20].

Table 1 : Difference between Wharton customer analytics \&Microsoft Analytics

\begin{tabular}{|l|l|l|}
\hline S. No. & Wharton customer analytics & Microsoft Analytics \\
\hline 1 & Developed by Wharton Business School & Developed by Microsoft Corp \\
\hline
\end{tabular}

Sachin Kumar, et al, (2020); www.srinivaspublication.com 


\begin{tabular}{|c|c|c|}
\hline 2 & Faculty and Researcher Developed it & Microsoft Developers Developed it \\
\hline 3 & Net Promoter Score is $66.54 \%$ & Net Promoter Score is $60 \%$ \\
\hline 4 & Customer satisfaction score is $25 \%$ & Customer satisfaction score is $13.7 \%$ \\
\hline 5 & Retention or Repeat Customers is $74.50 \%$ & Retention or Repeat Customers is $80 \%$ \\
\hline 6 & Churn rate is positive & Churn rate is positive \\
\hline 7 & $\begin{array}{l}\text { Customer Effort Score makes top decisions } \\
\text { with data. }\end{array}$ & $\begin{array}{l}\text { Customer Effort Score from } 1 \text { to } 5 \text { (on the } \\
7 \text {-point scale) increased their loyalty by } \\
22 \% \text {. }\end{array}$ \\
\hline 8 & Average Resolution Time is $75 \%$ & Average Resolution Time is $28.3 \%$ \\
\hline 9 & $\begin{array}{l}\text { Customer Lifetime Value is } 13 \% \text { of } \\
\text { customers contributed } 75 \% \text { of revenue. }\end{array}$ & $\begin{array}{l}\text { Customer Lifetime Value is } 80 \% \text { of the } \\
\text { effect comes from } 20 \% \text { of the causes, this } \\
\text { is known as } 80 / 20 \text { rule. }\end{array}$ \\
\hline 10 & $\begin{array}{l}\text { Social Sentiment is not } 100 \% \text { accurate } \\
\text { because no tool or human is } 100 \% \text { right but } \\
\text { it's pretty close. }\end{array}$ & $\begin{array}{l}\text { Social Sentiment is values close to } 1 \\
\text { indicate greater confidence that the } \\
\text { sentiment is accurate. }\end{array}$ \\
\hline 11 & Reviews and ratings are $100 / 100$. & $\begin{array}{l}\text { Reviews and ratings is to track the overall } \\
\text { task \& productive hours of user along with } \\
\text { how the user utilize the available time. }\end{array}$ \\
\hline 12 & $\begin{array}{l}\text { Referral rates increases the conversation } \\
\text { rate of new customers by } 86 \% \text {. }\end{array}$ & Referral rates is $97.1 \%$. \\
\hline
\end{tabular}

Table 2 :Difference between Wharton customer analytics \&Agile Analytics

\begin{tabular}{|c|c|c|}
\hline S. No. & Wharton customer analytics & Agile Analytics \\
\hline 1 & Developed by Wharton Business School & Developed by Sisense \\
\hline 2 & Faculty and Researcher Developed it & Ken Collier Who Developed it \\
\hline 3 & Net Promoter Score is $66.54 \%$ & Net Promoter Score is $55 \%$ \\
\hline 4 & Customer satisfaction score is $25 \%$ & Customer satisfaction score is $100 \%$ \\
\hline 5 & Retention or Repeat Customers is $74.50 \%$ & Retention or Repeat Customers is $80 \%$ \\
\hline 6 & Churn rate is positive & Churn Rate is positive \\
\hline 7 & $\begin{array}{l}\text { Customer Effort Score makes top decisions } \\
\text { with data. }\end{array}$ & $\begin{array}{l}\text { Customer Effort Score differs from CSAT } \\
\text { and NPS in that it doesn't directly measure } \\
\text { satisfaction, as such. }\end{array}$ \\
\hline 8 & Average Resolution Time is $75 \%$ & Average Resolution Time is $86.80 \%$ \\
\hline 9 & $\begin{array}{l}\text { Customer Lifetime Value is } 13 \% \text { of } \\
\text { customers contributed } 75 \% \text { of revenue. }\end{array}$ & $\begin{array}{l}\text { Customer Lifetime Value is the expected } \\
\text { number of future transactions } \\
\text { the customer will make and the probability } \\
\text { they are retained. }\end{array}$ \\
\hline 10 & $\begin{array}{l}\text { Social Sentiment is not } 100 \% \text { accurate } \\
\text { because no tool or human is } 100 \% \text { right but } \\
\text { it's pretty close. }\end{array}$ & $\begin{array}{l}\text { Social Sentiment requires no labelled } \\
\text { exemplars of positive and negative } \\
\text { sentiment for implementation. }\end{array}$ \\
\hline 11 & Reviews and ratings are $100 / 100$. & Reviews and ratings are $44 / 100$. \\
\hline 12 & $\begin{array}{l}\text { Referral rates increases the conversation } \\
\text { rate of new customers by } 86 \% \text {. }\end{array}$ & Referral rates is $99 \%$. \\
\hline
\end{tabular}

Table 3 :Difference between Wharton customer analytics \&SAS Analytics :

\begin{tabular}{|l|l|l|}
\hline S. No. & Wharton customer analytics & SAS Analytics \\
\hline 1 & Developed by Wharton Business School & Developed by SAS Institute in America \\
\hline 2 & Faculty and Researcher Developed it & Developers of SAS Institute Developed it \\
\hline 3 & Net Promoter Score is $66.54 \%$ & $\begin{array}{l}\text { Net Promoter Score is } 57 \% \text { are considered } \\
\text { to be excellent. }\end{array}$ \\
\hline 4 & Customer satisfaction score is $25 \%$ & $\begin{array}{l}\text { Customer satisfaction score will be 22 } \\
\text { percent, and net revenues will improve by } \\
1.5 \text { percent }\end{array}$ \\
\hline
\end{tabular}

Sachin Kumar, et al, (2020); www.srinivaspublication.com 


\begin{tabular}{|l|l|l|}
\hline 5 & Retention or Repeat Customers is 74.50\% & Retention or Repeat Customers is $44 \%$. \\
\hline 6 & Churn rate is positive & Churn rate is very high \\
\hline 7 & $\begin{array}{l}\text { Customer Effort Score makes top decisions } \\
\text { with data. }\end{array}$ & $\begin{array}{l}\text { Customer Effort Score which ones can be } \\
\text { improved. }\end{array}$ \\
\hline 8 & Average Resolution Time is $75 \%$ & $\begin{array}{l}\text { Average Resolution Time is 1 hour due to } \\
\text { average arrival and processing rates. }\end{array}$ \\
\hline 9 & $\begin{array}{l}\text { Customer Lifetime Value is 13\% of } \\
\text { customers contributed 75\% of revenue. }\end{array}$ & $\begin{array}{l}\text { Customer Lifetime Value is positive } \\
\text { changes in overall company revenue and } \\
\text { churn. }\end{array}$ \\
\hline 10 & $\begin{array}{l}\text { Social Sentiment is not } 100 \% \text { accurate } \\
\text { because no tool or human is } 100 \% \text { right but } \\
\text { it's pretty close. }\end{array}$ & $\begin{array}{l}\text { Social Sentiment is allowing businesses to } \\
\text { get a better understanding of the feelings } \\
\text { behind user-generated content. }\end{array}$ \\
\hline 11 & $\begin{array}{l}\text { Reviews and ratings are 100/100. } \\
\text { Reviews and ratings are is excellent for } \\
\text { data exploration. }\end{array}$ \\
\hline 12 & $\begin{array}{l}\text { Referral rates increases the conversation } \\
\text { rate of new customers by } 86 \% .\end{array}$ & \begin{tabular}{l} 
Referral rates are $75 \%$. \\
\hline
\end{tabular} \\
\hline
\end{tabular}

Table 4 : Difference between Wharton customer analytics \&Hamill Educational Analytics:

\begin{tabular}{|c|c|c|}
\hline S. No. & Wharton customer analytics & Hamill Educational Analytics \\
\hline 1 & Developed by Wharton Business School & Developed by Hamill \\
\hline 2 & Faculty and Researcher Developed it & Dr. Hamill Developed it. \\
\hline 3 & Net Promoter Score is $66.54 \%$ & Net Promoter Score is $60 \%$. \\
\hline 4 & Customer satisfaction score is $25 \%$ & Customer satisfaction score is $20 \%$. \\
\hline 5 & Retention or Repeat Customers is $74.50 \%$ & Retention or Repeat Customers is $40 \%$. \\
\hline 6 & Churn rate is positive & Churn rate is very less nearly $10 \%$. \\
\hline 7 & $\begin{array}{l}\text { Customer Effort Score makes top decisions } \\
\text { with data. }\end{array}$ & $\begin{array}{l}\text { Customer Effort Score leads to better } \\
\text { customer loyalty and satisfaction than } \\
\text { customer delight. }\end{array}$ \\
\hline 8 & Average Resolution Time is $75 \%$ & Average Resolution Time is $80.8 \%$ \\
\hline 9 & $\begin{array}{l}\text { Customer Lifetime Value is } 13 \% \text { of } \\
\text { customers contributed } 75 \% \text { of revenue. }\end{array}$ & Customer Lifetime Value is $74.26 \%$ \\
\hline 10 & $\begin{array}{l}\text { Social Sentiment is not } 100 \% \text { accurate } \\
\text { because no tool or human is } 100 \% \text { right but } \\
\text { it's pretty close. }\end{array}$ & Social Sentiment is not good. \\
\hline 11 & Reviews and ratings are $100 / 100$. & $\begin{array}{l}\text { Reviews and ratings are the good one and } \\
\text { its } 21^{\text {st }} \text { century analytics. }\end{array}$ \\
\hline 12 & $\begin{array}{l}\text { Referral rates increases the conversation } \\
\text { rate of new customers by } 86 \% \text {. }\end{array}$ & Referral rates are $70 \%$. \\
\hline
\end{tabular}

Table 5: Difference between Wharton customer analytics \&GitHub Educational Analytics :

\begin{tabular}{|l|l|l|}
\hline S. No. & Wharton customer analytics & GitHub Educational Analytics \\
\hline 1 & Developed by Wharton Business School & Developed by GitHub Corp \\
\hline 2 & Faculty and Researcher Developed it & $\begin{array}{l}\text { Students Developers of GitHub Developed } \\
\text { it. }\end{array}$ \\
\hline 3 & Net Promoter Score is $66.54 \%$ & Net Promoter Score is $90 \%$ \\
\hline 4 & Customer satisfaction score is $25 \%$ & Customer satisfaction score is $35 \%$ \\
\hline 5 & Retention or Repeat Customers is $74.50 \%$ & Retention or Repeat Customers is $60 \%$ \\
\hline 6 & Churn rate is positive & Churn rate is positive \\
\hline 7 & $\begin{array}{l}\text { Customer Effort Score makes top decisions } \\
\text { with data. }\end{array}$ & Customer Effort Score is $96 \%$ \\
\hline 8 & Average Resolution Time is $75 \%$ & Average Resolution Time is $70 \%$ \\
\hline
\end{tabular}




\section{International Journal of Case Studies in Business, IT, and Education SRINIVAS (IJCSBE), ISSN: 2581-6942, Vol. 4, No. 2, August 2020.

\begin{tabular}{|l|l|l|}
\hline 9 & $\begin{array}{l}\text { Customer Lifetime Value is 13\% of } \\
\text { customers contributed 75\% of revenue. }\end{array}$ & $\begin{array}{l}\text { Customer Lifetime Values are using } \\
\text { Gamma-Gamma model to estimate average } \\
\text { transaction value for each customer. }\end{array}$ \\
\hline 10 & $\begin{array}{l}\text { Social Sentiment is not } 100 \% \text { accurate } \\
\text { because no tool or human is } 100 \% \text { right but } \\
\text { it's pretty close. }\end{array}$ & Social Sentiment is excellent. \\
\hline 11 & Reviews and ratings are 100/100. & $\begin{array}{l}\text { Reviews and ratings of GitHub has become } \\
\text { a key social platform for managing projects } \\
\text { and facilitating collaborative development } \\
\text { within the software development } \\
\text { community. }\end{array}$ \\
\hline 12 & $\begin{array}{l}\text { Referral rates increases the conversation } \\
\text { rate of new customers by } 86 \% .\end{array}$ & Referral rates are $70 \%$. \\
\hline
\end{tabular}

Table 6 : Difference between Wharton customer analytics \&Assembly Analytics :

\begin{tabular}{|l|l|l|}
\hline S. No. & Wharton customer analytics & Assembly Analytics \\
\hline 1 & Developed by Wharton Business School & Developed by Multi Academy Trust \\
\hline 2 & Faculty and Researcher Developed it & Students of MAT Developed it \\
\hline 3 & Net Promoter Score is $66.54 \%$ & Net Promoter Score is 65\%. \\
\hline 4 & Customer satisfaction score is $25 \%$ & Customer satisfaction score is $59 \%$ \\
\hline 5 & Retention or Repeat Customers is $74.50 \%$ & Retention or Repeat Customers is $65 \%$ \\
\hline 6 & Churn rate is positive & Churn rate is high \\
\hline 7 & $\begin{array}{l}\text { Customer Effort Score makes top decisions } \\
\text { with data. }\end{array}$ & $\begin{array}{l}\text { Customer Effort Score is used to improve } \\
\text { retention. }\end{array}$ \\
\hline 9 & $\begin{array}{l}\text { Average Resolution Time is 75\% } \\
\text { customer Lifetime Value is 13\% of }\end{array}$ & Average Resolution Time is $65 \%$ \\
\hline 10 & $\begin{array}{l}\text { Cocial Sentiment is not } 100 \% \text { accurate } \\
\text { because no tool or human is } 100 \% \text { right but } \\
\text { it's pretty close. }\end{array}$ & Social Sentiment is nearly $75 \%$. \\
\hline 11 & $\begin{array}{l}\text { Reviews and ratings are } 100 / 100 . \\
\text { Referral rates increases the conversation } \\
\text { rate of new customers by } 86 \% .\end{array}$ & Reviews and ratings are $43 \%$. \\
\hline 12 & \multicolumn{2}{|l}{ Rerral rates is $87.55 \%$} \\
\hline
\end{tabular}

By comparing Wharton customer analytics with other types of analytics on different parameters it was found that Wharton customer analytics have edge over other types of analytics.

\section{CONCLUSION :}

Organizations making better decisions have also achieved greater success. The difference in the age of big data is that by using the power of market analytics, businesses can now progress quickly and on a scale. By using advanced techniques such as machine learning and artificial intelligence, gleaning indepth insights from data troves are not the result of happening now, but rather a matter of course. Today's market leaders use tomorrow's innovations to make revolutionary strides in how they derive profit from their outcomes. Wharton Business School, founded and recognized as the first and oldest business school in the United States, retains its reputation by offering its students creative and high-quality education, thereby ensuring academic excellence. By putting equal focus on scientific advancement, it has maintained its policy of generating new information by starting and promoting the number of research centers and thereby maintaining success in terms of the number of School researchers and the number of published B-School research articles. It is also argued that Wharton Business School has been able to dominate and stand out as a role model in many areas of innovation in higher education relative to other top business schools in the U.S. as well as around the world by consistently implementing the monopoly strategy, and has been the global pioneer in achieving corporate search for 


\section{International Journal of Case Studies in Business, IT, and Education SRINIVAS (IJCSBE), ISSN: 2581-6942, Vol. 4, No. 2, August 2020. \\ PUBLICATION}

excellence [21-22]. Through developing and offering educational analytics, called Wharton customer analytics (WCA), Wharton business school created an edge over other types of analytics [23].

\section{REFERENCES :}

[1] Aithal, P. S. (2017). An Effective Method of Developing Business Case Studies based on Company Analysis, International Journal of Engineering Research and Modern Education (IJERME), 2(1), 1627.

[2] Aithal, P. S. (2017). Industry Analysis - The First Step in Business Management Scholarly Research. International Journal of Case Studies in Business, IT and Education (IJCSBE), 2(1), 1-13.

[3] Bhandari, G., Bussiere, D., \& Voyer, P. (2018). How loud is the Scream of a Clickstream? Insights from Big Data Analysis. Twenty-fourth Americas Conference on Information Systems, New Orleans, 2018, 1-5.

[4] Pfeffer, J., \& Fong, C. T. (2004). The business school 'business': Some lessons from the US experience. Journal of management studies, 41(8), 1501-1520.

[5] Hu, E. Y. (2017). Do Undergraduate Business Schools Cultivate Creative Thinking: The Wharton Curriculum as a Case in Point, Joseph Wharton Scholars. Available at https://repository.upenn.edu/joseph_wharton_scholars/27.

[6] Vidgen, R., Shaw, S., \& Grant, D. B. (2017). Management challenges in creating value from business analytics. European Journal of Operational Research, 261(2), 626-639.

[7] Henia, R., Hamann, A., Jersak, M., Racu, R., Richter, K., \& Ernst, R. (2005). System level performance analysis-the SymTA/S approach. IEE Proceedings-Computers and Digital Techniques, 152(2), 148-166.

[8] Varun Shenoy \& Aithal, P. S. (2017). Placement Strategies of World's Top Business Schools. International Journal of Management, Technology, and Social Sciences (IJMTS), 2(1), 6-17.

[9] Vidaver-Cohen, D. (2007). Reputation beyond the rankings: A conceptual framework for business school research. Corporate Reputation Review, 10(4), 278-304.

[10] Opara-Martins, J., Sahandi, R., \& Tian, F. (2015, October). Implications of integration and interoperability for enterprise cloud-based applications. In International Conference on Cloud Computing (pp. 213-223). Springer, Cham.

[11] Rubel, A., \& Jones, K. M. (2016). Student privacy in learning analytics: An information ethics perspective. The information society, 32(2), 143-159.

[12] Pardo, A., \& Siemens, G. (2014). Ethical and privacy principles for learning analytics. British Journal of Educational Technology, 45(3), 438-450.

[13] Brandys, S., Cakmak, U., Cmielowski, L., \& Solarski, M. (2017, October). From model building to analytics solution in hours the enterprise platform for analytics teams. In 2017 International Conference on Behavioral, Economic, Socio-cultural Computing (BESC) (pp. 1-3). IEEE.

[14] Lilien, G. L. (2016). The B2B knowledge gap. International Journal of Research in Marketing, 33(3), 543-556.

[15] Skiera, B. (2016). Data, data and even more data: Harvesting insights from the data jungle. Marketing Intelligence Review, 8(2), 10-17.

[16] Graham, A. K., Morecroft, J. D., Senge, P. M., \& Sterman, J. D. (1992). Model-supported case studies for management education. European Journal of Operational Research,59(1), 151-166.

[17] Phelps, J., Nowak, G., \& Ferrell, E. (2000). Privacy concerns and consumer willingness to provide personal information. Journal of Public Policy \& Marketing, 19(1), 27-41. 
[18] Mazzarol, T., Norman Soutar, G., \& Sim Yaw Seng, M. (2003). The third wave: Future trends in international education. International Journal of Educational Management, 17(3), 90-99.

[19] Leitner, P., Khalil, M., \& Ebner, M. (2017). Learning analytics in higher education-a literature review. In Learning analytics: Fundaments, applications, and trends (pp. 1-23). Springer, Cham.

[20] Aithal, P. S. \& Shubhrajyotsna Aithal (2016). Impact of On-line Education on Higher Education System. International Journal of Engineering Research and Modern Education (IJERME), 1(1), 225235.

[21] Aithal, A., \& Aithal, P. S. (2018). How and Why Wharton Business School became World Topper-A Case Study on Organizational Quest for Excellence of First US Business School. International Journal of Application or Innovation in Engineering \& Management (IJAIEM), 7(1), 15-42.

[22] Balbay, S. \& Kilis, S. (2018). Educational analytics on an open courseware. International Online Journal of Education and Teaching (IOJET), 5(3). 673-685. http://iojet.org/index.php/IOJET/article/view/456/261

[23] Pal, S. (2012). Mining educational data to reduce dropout rates of engineering students. International Journal of Information Engineering and Electronic Business, 4(2), 1-7. 